\title{
THE LINKS BETWEEN CLIMATE CHANGE, DISASTERS, MIGRATION, AND SOCIAL RESILIENCE IN ASIA: A LITERATURE REVIEW
}

Kayly Ober

NO. 586

July 2019
ADB ECONOMICS WORKING PAPER SERIES 


\section{The Links between Climate Change, Disasters, Migration, and Social Resilience in Asia: A Literature Review}

Kayly Ober

No. 586 | July 2019
Kayly Ober (kober@uni-bonn.de) is a PhD candidate from the University of Bonn.

This paper was prepared as background material for the Asian Development Outlook 2019 theme chapter on

"Strengthening Disaster Resilience." 
(C) 2019 Asian Development Bank 6 ADB Avenue, Mandaluyong City, 1550 Metro Manila, Philippines

Tel +632632 4444; Fax +6326362444

www.adb.org

Some rights reserved. Published in 2019.

ISSN 2313-6537(print), 2313-6545 (electronic)

Publication Stock No. WPS190231-2

DOI: http://dx.doi.org/10.22617/WPS190231-2

The views expressed in this publication are those of the authors and do not necessarily reflect the views and policies of the Asian Development Bank (ADB) or its Board of Governors or the governments they represent.

ADB does not guarantee the accuracy of the data included in this publication and accepts no responsibility for any consequence of their use. The mention of specific companies or products of manufacturers does not imply that they are endorsed or recommended by ADB in preference to others of a similar nature that are not mentioned.

By making any designation of or reference to a particular territory or geographic area, or by using the term "country" in this document, $A D B$ does not intend to make any judgments as to the legal or other status of any territory or area.

This work is available under the Creative Commons Attribution 3.0 IGO license (CC BY 3.0 IGO)

https://creativecommons.org/licenses/by/3.o/igo/. By using the content of this publication, you agree to be bound by the terms of this license. For attribution, translations, adaptations, and permissions, please read the provisions and terms of use at https://www.adb.org/terms-use\#openaccess.

This CC license does not apply to non-ADB copyright materials in this publication. If the material is attributed to another source, please contact the copyright owner or publisher of that source for permission to reproduce it. $\mathrm{ADB}$ cannot be held liable for any claims that arise as a result of your use of the material.

Please contact pubsmarketing@adb.org if you have questions or comments with respect to content, or if you wish to obtain copyright permission for your intended use that does not fall within these terms, or for permission to use the ADB logo.

Corrigenda to ADB publications may be found at http://www.adb.org/publications/corrigenda.

Notes:

In this publication, “\$” refers to United States dollars.

ADB recognizes "China" as the People's Republic of China and "Hanoi" as Ha Noi.

The ADB Economics Working Paper Series presents data, information, and/or findings from ongoing research and studies to encourage exchange of ideas and to elicit comment and feedback about development issues in Asia and the Pacific. Since papers in this series are intended for quick and easy dissemination, the content may or may not be fully edited and may later be modified for final publication. 


\section{CONTENTS}

ABSTRACT iii

$\begin{array}{ll}\text { I. INTRODUCTION } & 1\end{array}$

II. HOW DISASTERS AFFECT HUMAN MOBILITYIN ASIA 2

A. Background 2

B. Disasters in Asia $\quad 4$

III. HOW HUMAN MOBILITY IMPACTS VULNERABILITY AND RESILIENCE 6 TO DISASTERS

IV. FUTURE TRENDS IN CLIMATE-RELATED DISASTER-INDUCED MOBILITY 8

REFERENCES 


\begin{abstract}
This working paper was written as input for the Asian Development Outlook 2019. It reviews the literature at the intersection of disasters and migration in Asia and details the story of how disasters may affect mobility, from displacement to voluntary migration to "trapped populations." It also provides an overview of the "migration as adaptation" literature, which shows that planned and sustained movement may help individuals weather shocks and diversify income in the face of disaster, as well as the uneven outcomes of disaster-related remittances in Asia. In addition, it gives insight into predicted impacts on mobility because of climate-related disasters and delves into the likely trends. Ultimately, it aims to show the diverse ways in which disaster-related migration may affect economic growth and social resilience in Asia.
\end{abstract}

Keywords: climate change, disasters, migration, remittances, resilience

JEL codes: J60, O15, Q54 


\section{INTRODUCTION}

A more mobile world. Today's world is increasingly mobile, with an estimated 244 million international migrants (UNDESA 2015) and between 740 million and 763 million internal migrants globally (UNDP 2009, Bell and Charles-Edwards 2013). Asia is no exception: UNDESA (2015) estimates that more than $30 \%$ of all international migration occurred in Asia and nearly 50\% of international migrants came from Asia, particularly Afghanistan, Bangladesh, India, Pakistan, and the People's Republic of China (IOM 2018). While internal migrant numbers are harder to specify, the People's Republic of China alone is estimated to have more than 150 million rural-urban migrants (Chan 2013). Most internal and international migration is voluntary and in search of better economic opportunities, while also comprising an essential part of rural livelihoods in this part of the world (Adger et al. 2002; Deshingkar 2012; Rigg, Promphaking, and Le Mare 2014; Rigg, Nguyen, and Luong 2014; Rigg and Salamanca 2011, 2009).

Slow- and rapid-onset disasters. Disasters affect the movement of people in other ways. ${ }^{1}$ In general, sudden-onset events, which include tropical storms (hurricanes, cyclones, typhoons); flooding; and earthquakes, often lead to displacement (see Box to understand definitions of human mobility in more detail); whereas slow-onset events give communities and households more time to make voluntary migration decisions, although whether they see the need to migrate or relocate varies (Koubi et al. 2016). Asia, one of the most vulnerable regions in the world to sudden-onset events (WorldRiskReport 2017), has experienced several displacement-inducing disasters. In 2017, more than 18.8 million people were displaced by sudden-onset disasters worldwide, with East Asia and South Asia accounting for 11.4 million, or more than $60 \%$, of that total (IDMC 2018). ${ }^{2}$ At the same time, there is increasing concern over slow-onset disasters, especially as they relate to climate change. By 2050 , the World Bank predicts there will be about 140 million internal climate migrants, 60 million in South Asia alone, because of water scarcity, crop failure, sea level rise, and storm surges (Rigaud et al. 2018).

From numbers to nuances. Net numbers, however, tell us little about how disasters impact the movement of people in Asia, and the extent to which they affect people's ability to overcome poverty and build resilience. Thus, this paper seeks to move from numbers to nuances: What role do disasters play in making the decision to move? In what ways do disasters determine where, when, and how people move? How do disasters affect this movement across differentiated segments of society, including socioeconomic status, gender, and age? And, in what ways does migration affect vulnerability and resilience in the face of disaster?

\footnotetext{
Disasters are defined here as "serious disruption of the functioning of a community or society causing widespread human, material, economic or environmental losses which exceed the ability of the affected community or society to cope using its own resources" (UNDRR 2018).

2 The IDMC counts storms, floods, wildfires, wet mass movements, earthquakes, volcanic eruptions, extreme temperature, and dry mass movements in their estimates of sudden-onset disasters. Floods and storms account for approximately twothirds of all displacements (IDMC 2015. http://www.internal-displacement.org/publications/global-estimates-2015people-displaced-by-disasters).
} 


\section{What Is Human Mobility?}

Human mobility is an umbrella term for diverse sorts of movements of people. Importantly, it is meant to provide a holistic representation of movements that occur that may be voluntary, involuntary, or somewhere in between (see figure). These movements may be short or long term, and may occur over short or long distances, and within countries or across borders. They may involve one individual, a household, or even whole communities. The reasons behind these movements may also be diverse.

This working paper focuses largely on migration, which implies longer-term movements of people away from their places of origin, usually beyond subnational administrative units, and is normally voluntary in nature; and "displacement," or forced, sudden movements in the face of a risk or hazard. It is most interested in how these two sorts of movements relate to and are affected by disasters. At the same time, it recognizes that most movement postdisaster may be a combination of the two or a shift between one form and the other.

\section{The Human Mobility Spectrum}

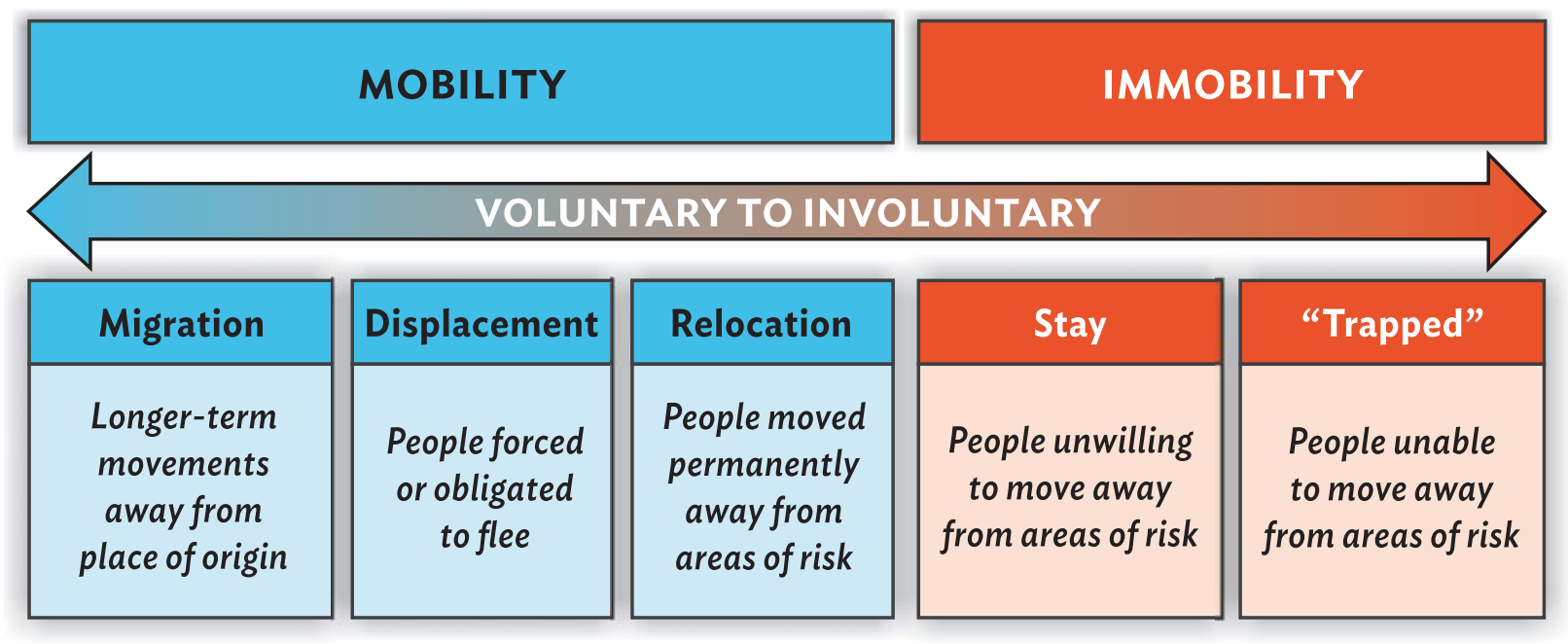

Source: Adapted from Rigaud et al. (2018).

\section{HOW DISASTERS AFFECT HUMAN MOBILITY IN ASIA}

\section{A. Background}

Factors in migration decision-making. The factors influencing migration decisions are multifaceted and complex. The often-cited push-pull theory (Lee 1966) suggests that factors in sending area (e.g., poverty, lack of opportunities) and destination area (e.g., jobs, social services, family members, social networks), as well as intervening obstacles (e.g., travel costs or border controls), and personal factors (e.g., age, gender, ethnicity) may influence migration decisions. However, in most cases, the drivers behind migration decisions are more ambiguous, and the resulting migration itself may be more complex than "going" or "staying." As the New Economics of Labor Migration theory finds, migration decisions are often taken as part of a household's collective strategy to diversify income sources and reduce exposure to risk (Stark and Bloom 1985, Scoones 1998). In most instances, this migration may be cyclical, where migrants leave during the dry season to bolster income as seasonal agricultural 
laborers or in the service industry in cities, for example. In other cases, household members may migrate permanently, but retain strong ties back home and remittance obligations (Mazzucato 2011).

Additional factors that influence migration decisions at the household level relate to the size of the household and the age and gender configuration of its members. A household with many members may be better able to spare the labor lost when a migrant departs than a household with fewer members (Gray and Mueller 2012a, Warner and Afifi 2014). The likelihood of any household member migrating is often closely linked to the age and life-course stage of household members, with young, unmarried adults being the most likely to contemplate migration (Plane 1993). In some societies, cultural barriers restrict the mobility of women, whereby men migrate most and are expected to be the breadwinners. This may result in households headed by women or the elderly, who may be in charge of rearing children alone or as a stand-in caretaker for the labor migrants of the household (Rigg and Salamanca 2015; Rigg, Promphaking, and Le Mare 2014; Rigg, Salamanca, and Parnwell 2012). While these households may become more vulnerable in some ways, other households that do not have the capital or capacity to migrate may be worse off, becoming "trapped" (Black et al. 2011). ${ }^{3}$

Unique mobility responses. The ways in which migration decisions play out in the face of a disaster are different than in other, less pressing circumstances, such as the search for economic opportunities. During sudden-onset disasters, people often make decisions quickly and under duress (World Bank 2016), typically moving as part of a large, networked group responding to an exogenous push (Drabek and Boggs 1968). Because of this, these sorts of movements are often categorized as displacement rather than migration, although it is generally acknowledged that these mobility responses exist on a spectrum and often overlap (Box). The scale and scope of displacement is largely determined by the underlying vulnerability of people and communities to shocks or stresses, the magnitude and frequency of the hazard event at hand, and the ability to cope with such events (IDMC 2015). The circumstances and contexts of communities and households are important factors in understanding the resulting displacement (Hunter 2005), including the speed of onset of the disaster (both in terms of its rate of onset and the ability of those affected to perceive the risk and adapt in anticipatory fashion) (Renaud et al. 2011, Koubi et al. 2016); the household's assets; access to land and natural resources; community assistance; social networks (McLeman and Smit 2006, Warner 2012); aid response; and likelihood of recurrence (Naik 2009). Thus, people displaced by disasters are often among the most vulnerable (Ginnetti and Lavell 2015, Rigaud et al. 2018).

The scale of the resulting movement may be large or small depending on the type of disaster (Blaikie et al. 1994; Brock and Paul 2003; Cannon 1994; Lavell 1994; Parker, Islam, and Chen 1997; Smith and Ward 1998). For example, sudden-onset hazards tend to generate different sorts of mobility, often resulting in migration "churns"-a mix of short-term and longer-term out-migration and, at times, sudden influxes of migrants into affected areas to help rebuild (Curtis, Fussell, and DeWaard 2015; DeWaard, Curtis, and Fussell 2016). Slow-onset events on the other hand normally do not generate immediate changes in existing migration patterns (McLeman 2014).

Both slow- and sudden-onset disasters largely result in internal, localized (Smith and McCarty 1996), and short-term movements (Hugo 1996; Hugo 2006; Massey, Axinn, and Ghimire 2007). Several qualitative studies bear this out, showing that flooding or coastal storms induce mostly shortterm and temporary movement (Findlay and Geddes 2011; Kartiki 2011; Mallick, Ahmed, and Vogt

3 "Trapped" populations, as defined by Black et al. (2011), are people who will be unable to move away from locations in which they are extremely vulnerable to environmental change due to their limited capital and capacities, despite wanting and needing to do so. 
2017; Mallick and Vogt 2014; Paul 2005; Paul and Routray 2010; Penning-Rowsell, Sultana, and Thompson 2013; Rahman et al. 2015). This trend holds even in the face of larger-scale disasters: For example, after Hurricane Andrew in 1992, 80\% of evacuees returned within a month (Smith and McCarty 1996). Similarly, more than $50 \%$ of migrants returned to New Orleans within 7 months after Hurricane Katrina, although the rate of return varied according to socioeconomic status and race, with white residents returning sooner than black ones (Fussell, Sastry, and VanLandingham 2010).

The spatial distribution of postdisaster movement depends on preexisting migrant networks and other forms of capital (Hugo 1996, McLeman and Smit 2006). Frequently, displacement occurs at the nearest safe point (Raleigh, Jordan, and Salehyan 2008). However, other calculations are made, including using existing social networks to determine "locations that match their needs for place-based resources such as disaster assistance, affordable housing, employment opportunities, neighborhood amenities, and public services" (Fussell, Sastry, and VanLandingham 2010). In addition, in developing country contexts, especially in rural areas, affected populations tend to migrate to large cities in search of opportunities to recover economically from the impact (Lein 2000, Lewis 1999).

\section{B. Disasters in Asia}

Risk distribution uneven. The risk of disaster-induced displacement is unevenly distributed around the world and within Asia in particular. Displacement risk is unevenly distributed among countries within Asia because of differences such as population size, exposure to different types of hazards, and preexisting vulnerabilities and resilience (Ginetti and Lavell 2015). For example, according to the IDMC (2015), 1 million people in India risk displacement for every one person in the Maldives. However, when population size is accounted for, they find that individual people in the Maldives are 3 times as likely to be displaced as people in India. Similarly, Asia has a large and growing number of coastal megacities, significantly increasing the population exposed to displacement risks posed by sudden-onset events (ADB 2012).

Disaster type and scale impact movements. The ways in which disasters affect mobility in Asia follow some instructive trends echoed in the general literature. Firstly, the type of disaster and its relative scale will impact resulting movements. Sudden-onset events, such as tropical storms, typically cause significant displacement throughout Asia (Nansen Initiative 2014). For example, in 2011, monsoon rains and multiple tropical storms in Southeast Asia resulted in some of the region's worst flooding in 50 years, affecting Cambodia, the Lao People's Democratic Republic, Myanmar, Thailand, and Viet Nam. The Government of Thailand evacuated 1.5 million people from Bangkok (Yonetani 2012), and in Cambodia, about 214,000 people were displaced (FAO and WFP 2012). However, the magnitude of sudden-onset events will also determine the intensity of resulting movement. For instance, in November 2013, Typhoon Haiyan-one of the most powerful storms ever recorded-hit the Philippines, displacing 4 million people. Similarly, Cyclone Nargis struck Myanmar's Irrawaddy Delta in May 2008, displacing about 1.6 million people.

At the same time, recurring slow-onset hazards, such as the annual flooding in the Mekong and Irrawaddy Deltas, produce less dramatic patterns of movement. Since many rural communities are used to coping with and even depend upon these seasonal inundations, they tend to induce only moderate mobility (see Chun 2014, for Viet Nam; Gray and Mueller 2012b, for Bangladesh; Mueller, Gray, and Kosec 2014, for Pakistan). However, if these recurring slow-onset events are exacerbated by other disasters, such as cyclones, movement may be amplified (Gray and Mueller 2012b). Likewise, if the impacted population has to deal with slow-onset events outside of the norm, such as temperature 
extremes in Pakistan (Mueller, Gray, and Kosec 2014) or repeated drought in Bangladesh (Gray and Mueller 2012b), then out-migration increases. Most of this movement would be categorized as migration, although on a sliding scale of voluntary and involuntary, rather than displacement.

Movement predominantly local. Secondly, the nature of the movement tends to be local, or in some cases rural-urban. In the event of sudden-onset disasters, such as cyclones or earthquakes, people tend to move into surrounding areas (see Wilson et al. 2016 in Nepal; or Lu et al. 2016a, 2016b in Bangladesh). Existing social networks and support systems as well as emergency preparedness and early warning systems influence this spatial distribution (Lu et al. 2016b, Mallick 2014). In South Asia, in particular, rural-urban movement in the face of slow or sudden-onset disaster is commonplace (Bryan, Chowdhury, and Mobarak 2014; Deshingkar 2012; Gioli et al. 2014). For example, Mallick (2014) finds that almost 25\% of households affected by Cyclone Aila moved toward neighboring cities immediately after emergency relief works were phased out. Most (78\%) moved to big cities, including Satkhira, Khulna, and Bagerhat, where they sought jobs in the service industry (Mallick 2014).

Duration typically temporary. Thirdly, the duration of the movement is often temporary, barring extraordinary cases. While people tend to flee immediately in the face of sudden-onset disasters, they also tend to attempt to return as soon as possible. For example, Wilson et al. (2016) find that while an earthquake in Nepal displaced 390,000 people, most of those affected returned within 2 or 3 months. Even more surprising, Lu et al. (2016a, 2016b), using a novel retroactive large-scale mobile phone tracking system, find that during Cyclone Mahasen in 2013 in Bangladesh, most evacuees returned within 2 days. However, they note that Cyclone Mahasen was weak compared with other storms and these findings may not necessarily be replicated in the face of a larger storm or different sorts of hazards. Similar patterns were observed in Bangladesh following Cyclone Aila in 2009 (Mallick and Vogt 2012), but because of the scale of the event, the terms and rates of return were differentiated depending on the livelihood of impacted households. For example, because of postcyclone saline water intrusion on rice paddy fields, some rice farmers had to wait at least 2 years to make use of them. In the meantime, they chose to migrate to the city to find alternative work (Mallick, Ahmed, and Vogt 2017). Meanwhile, while a sudden-onset event, such as flooding, may induce migration and immediate return, slow-onset events, such as repeat high temperatures, have sustained effects on migration, which may persist for a year or 2 (Call et al. 2017).

Influence of socioeconomic status, gender, and education. The ability to weather a disaster shock and movements related to their impacts is often determined along socioeconomic, gender, and educational divides. The decision to move, how, when, where, and many other relevant outcomes are determined by the vulnerability or resilience of each household and the assets they have to make such decisions (Black et al. 2011, Ginnetti and Lavell 2015, Rigaud et al. 2018). On average, the poor are most likely to migrate when confronted with a sudden- or slow-onset event (Chun 2014; Gray and Mueller 2012a; Mallick 2014; Mallick and Vogt 2012; Mallick, Ahmed, and Vogt 2017; Mueller, Gray, and Kosec 2014; Tunas and Peresthu 2010). This is the case for various reasons, but most likely because of immediate and debilitating income shocks that need to be overcome through labor migration (Gray and Mueller 2012; Mallick 2014; Mallick, Ahmed, and Vogt 2017). At the same time, households with more assets, including housing, land, and education (Chun 2014; Gray et al. 2014; Mueller, Gray, and Kosec 2014), have a higher capacity to cope with or adapt to these shocks and are motivated to stay to safeguard these assets.

Socioeconomic factors may also determine the timing of the resulting movement. For example, Mallick (2014) finds that after Cyclone Aila in 2009, lower-income groups (those earning less than 
$\$ 30$ per month) started to move earlier (within 4 weeks after the event) and tried to settle in neighboring cities, whereas middle- and higher-income groups waited a little longer (at least 4 weeks after the event) before moving. However, it should also be noted that the poorest of the poor may be unable to migrate at all because they do not have the necessary income and assets to finance such a move (Bryan, Chowdhury, and Mobarak 2014; Mueller Gray, and Kosec 2014), leaving them trapped (Black et al. 2011).

Occupation also has an effect on timing and duration of movement. As highlighted earlier, during Cyclone Aila in 2009, waterlogging and saline intrusion rendered rice paddy fields unusable for cultivation for at least 2 years. As a result, most farmers dependent on them for their main source of income moved to cities or turned to fishing to supplement their income (Mallick, Ahmed, and Vogt 2017). However, results are not always consistent. Gray et al. (2014) find that farming households in Indonesia were less likely to move than nonfarming households after the tsunami. This may be because shocks to crop resources had decreased the resources necessary to make the move (Mueller, Gray, and Kosec 2014).

In Asia, and especially in South Asia, gender and attendant social norms significantly influence disaster-induced mobility. The type of disaster also determines the resulting movement along gender lines. For example, sudden-onset events, such as cyclones, may trap men and women differently. Ikeda (1995) finds that women's social norms and role behaviors, including restrictive clothing, limited education, and expectation to stay in the house of their family or kin, may limit mobility (and increase mortality) during cyclones in Bangladesh. Lu et al. (2016b) surmise that men in the Barisal Division may have stayed behind to protect their homes and assets from thieves during Cyclone Mahasen. At the same time, men are on average more likely to migrate following a disaster as part of their role as breadwinners for the household. For slow-onset events, such as increasing rainfall and temperature extremes, men are especially expected to migrate (Call et al. 2017; Mueller, Gray, and Kosec 2014). Call et al. (2017) find that high rainfall increases demand for farm labor and thus men's migration; while an increase in temperature increases men's probability of migration while simultaneously decreasing the probability for women. They also find that migration is more likely to occur for those between 15 and 35 years old, which follows the general literature in Asia where young, able-bodied cohorts are most likely to engage in labor migration (Rigg and Salamanca 2015; Rigg, Promphaking, and Le Mare 2014; Rigg, Nguyen, and Luong 2014; Rigg, Salamanca, and Parnwell 2012).

\section{HOW HUMAN MOBILITY IMPACTS VULNERABILITY AND RESILIENCE TO DISASTERS}

Migration as an adaptive response. There is an increasing preoccupation with disaster displacement, but mobility equally may bolster or hamper the ability to respond to disasters and influence longerterm effects. Both preexisting mobility patterns and postdisaster movement can be necessary and considered an appropriate adaptive response for individuals and households (Black et al. 2011, Ober 2014, Sakdapolrak et al. 2016). For example, the term "migration as adaptation" sees migration as a way for households to diversify their income (Black et al. 2011; Scheffran, Marmer, and Sow 2012; Tacoli 2011) and spread risk (Afifi et al. 2015). This is especially true for small farmers who rely on rainfed agriculture for their livelihood (Deshingkar 2012), where environmental shocks are commonplace and a lean season is typical (Bryan, Chowdhury, and Mobarak 2014). 
Remittances as disaster mitigation. Remittances act as a coping mechanism through consumption-smoothing effects and investment in housing and communication equipment to increase preparedness and to mitigate the impact of disasters (Ebeke and Combes 2013; Gubert 2002; Halliday 2006; Mohapatra, Joseph, and Ratha 2012; Quartey and Blankson 2004). In general, remittances can be transferred more rapidly and efficiently than relief efforts, allowing households to recover faster, as was found in Pakistan after the 2005 earthquake (Suleri and Savage 2006); in Samoa after the 2009 tsunami and 2012 cyclone (Le Dé, Gaillard, and Friesen 2015); and in Indonesia (Wu 2006) and Sri Lanka (Deshingkar and Aheeyar 2006) after the 2004 tsunami. Some of these recovery gains can be substantial: Yang and Choi (2007) find that financial remittances help to compensate for nearly $65 \%$ of the income lost because of rainfall shocks in the Philippines. Migration can also generate "social remittances" (Levitt 1998), increasing knowledge, capacity, and networks (Adger et al. 2003; Barnett and Webber 2010; Scheffran, Marmer, and Sow 2012) to build resilience to future disasters. At the same time, evidence of this type of remittance is sparse and inevitably context based (Kagan 2016).

Remittances and inequality. Some studies find remittances can increase inequality during disasters and extreme events, as most remittances reach those already privileged within a community and are often spent insularly to protect individual households (Adger et al. 2002, Le Dé et al. 2015). The poorest and most excluded can become even worse off after an event (Deshingkar and Aheeyar 2006, Le Dé et al. 2015). For example, in Nepal, remittance-receiving households allocated about 20\% of their remittance income on construction following the earthquake; meanwhile, for households that did not receive remittances, the intent to build a new home was significantly less (NRRC 2014). Similarly, remittances are not evenly spread across those most in need. In the Philippines, Licuanan, Toman, and Steinmayr (2012) find that donations mainly flow to provinces with high emigration rates, therefore not reaching the less developed provinces.

Determinants of resilient outcomes. Resilient outcomes from financial and/or social remittances depend on a complex set of inputs, trajectories, and histories. How, when, and why migrants send back remittances, what households decide to spend remittances on, whether migrants transfer social remittances, and how remittances are used all depend on the context and background in which the decisions take place. The reason behind remittance amount and timing depends on existing or enduring social relationships, such as kinship, as shown in Polynesian migrants (Brown, Connell, and Jimenez-Soto 2014); or a sense of obligation to family or religious values instilled by the community, as shown in Samoa (Le Dé, Gaillard, and Friesen 2015). When these ties decline, normally as migrants stay away from their hometowns and form new family or networks in their places of destination (Harper and Zubida 2017), so too does the amount of the remittances sent, as was found in Bangladesh and Viet Nam (Szabo, Adger, and Matthews 2018).

However, financial transfers from the larger diaspora can be essential postdisaster. If active diaspora institutions exist, they can facilitate these transfers more efficiently and effectively than social ties alone (Aldrich 2011). Likewise, the use of remittances may vary based on different characteristics or expectations of the household. For example, Kurien (2008) finds that in three Indian villages she studied, migrants from the Muslim village distributed money to a large circle of community members; Hindus spent large sums on life-cycle rituals; and in the Christian village, remittances supported family expenses, including dowries and education.

Impact of postdisaster remittances on resilience. Financial and social remittances postdisaster also have impacts over time and space that may increase or decrease long-term resilience. 
The feedback processes of migration on the places of origin of migrants have an impact on the environment (Davis and Lopez-Carr 2010, Greiner 2011, Greiner and Sakdapolrak 2013, Sakdapolrak et al. 2016) and on how people deal with environmental risks (Deshingkar 2012, Sakdapolrak et al. 2016), which in turn has implications for migration decisions and the ability to prepare for future disasters. The transfer of finances and ideas, as well as the return of migrants themselves (equipped with knowledge, capital, and aspirations) can contribute to agricultural innovation (Rockenbauch and Sakdapolrak 2017) through the introduction of new crops, technologies, and business models, which entail profound changes for local socioecological systems. For example, in Thailand, the increasing investment in sugar cane, rubber trees, or vegetables, and the introduction of new businesses such as chicken farming in the northeast of the country, often made possible by the financial and/or social remittances of return migrants (Rockenbauch and Sakdapolrak 2019, Peth and Sakdapolrak under review), has led to increasing use of fertilizers and pesticides, and to land degradation.

\section{FUTURE TRENDS IN CLIMATE-RELATED DISASTER-INDUCED MOBILITY}

Future trends likely to follow past patterns. Past patterns of mobility and outcomes can be instructive for future climate-related trends. Migration is not a stand-alone process, but rather occurs along social networks established by earlier generations of migrants (Bardsley and Hugo 2010, Massey et al. 1993). Even in extreme cases, most human movement resulting from climate change impacts is likely to follow or reinforce established channels of movement or at least depend upon established networks and relationships (Bardsley and Hugo 2010, Rigaud et al. 2018). Thus, most movement will occur internally within countries (ADB 2012, Hugo 1996, Rigaud et al. 2018).

The climate change wild card. However, climate change will influence disasters in drastic ways and the way in which humans have been able to manage disasters in the past may also change radically. While lessons learned are instructive, they do not prepare us for the abrupt, nonlinear changes to be expected under different climate change scenarios (Streets and Glantz 2000, Schneider 2004). Locations that already experience extreme storm events, especially in mid-latitudes and the wet tropics, should expect to experience disaster events of similar or greater frequency, with the potential for more high-intensity events through 2050 (IPCC 2013). The intensity of extreme storms is also likely to increase, heightening the risks of flooding and damage to homes and coastal infrastructure (Chan et al. 2012). The greater prevalence of extreme events will affect rural and urban communities, particularly on sloping lands and in coastal regions. Low-lying deltaic countries, such as Bangladesh, and small island developing states face some of the highest levels of exposure and vulnerability to extreme storm events (World Bank 2013).

Expected direct and indirect livelihood impacts. Other ways in which climate change can be expected to affect livelihoods and, as a consequence, patterns of mobility, include through direct impacts on the quality, quantity, and/or accessibility of ecosystem goods and services in particular locations; and through indirect effects on households' access to and reserves of other forms of capital. Direct and indirect impacts can be experienced concurrently. For example, the growing dryness, risk of extreme heat events, and changing precipitation patterns associated with climate change are expected to significantly reduce crop yields in less developed countries over coming decades. At the same time, the combined effects of a growing global population, increased demand for food, and a global food supply constrained by climate change are expected to make global food prices more volatile and negatively affect rural incomes (Mendelsohn et al. 2007). The direct impacts of lower crop yields and the indirect impacts of food price instability can together be 
expected to place considerable pressure on rural livelihoods, a dynamic sometimes described as "double exposure" (O’Brien and Leichenko 2000).

Scale of climate-induced migration. The estimates of climate-related migration in Asia are diverse, with one study projecting up to 60 million migrants in South Asia alone by 2050 (Rigaud et al. 2018). The spatial distribution of these migrants is uneven across the region. Since climate-related out-migrations occur in areas of deteriorating water availability and crop productivity, hotspots include the northern part of the Gangetic Plain and parts of the broader Gangetic Plain and the Delhi-Lahore corridor. Sea level rise and storm surge impacts will dampen growth in major coastal metropolitan areas such as Chennai, Chittagong, Dhaka, and Mumbai. For example, Mumbai, a low-lying city vulnerable to cyclones and severe flooding, may become less hospitable, especially under a highemissions pathway, which projects a sea level rise of 2 meters by 2050 . However, declining crop productivity raises the high likelihood of movement toward sources of income that are not dependent on climate in cities such as Hyderabad and Karachi, amplifying already existing patterns of rural-urban migration. Climate impacts are also especially dire for low-lying deltaic countries, such as Bangladesh, where the same study projects 13 million internal climate migrants by 2050 (Rigaud et al. 2018).

Determinants of movement outcomes. Despite the scale of movement, who moves and how they do so are more important in determining the outcomes of disaster-related movement. Studies of climate-related slow-onset events find that they influence both short- and long-distance movement (Call et al. 2017, Gray et al. 2014, Gray and Mueller 2012b, Jennings and Gray 2017) but can also decrease movement for some segments of each population based on gender, education, and/or wealth constraints (Call et al. 2017; Mueller, Gray, and Kosec 2014). The ability or capacity to move can be a positive outcome if the disaster in question severely limits livelihood options. As Rigaud et al. (2018) also emphasize, climate-related migration does not necessarily signal a failure to adapt or mean moving under duress. Depending on the institutional and policy context, some migration may result in positive and nonmaladaptive outcomes, with consequences for long-term, future development (Black et al. 2011, Geddes and Jordan 2012). 


\section{REFERENCES}

Asian Development Bank (ADB). 2012. Addressing Climate Change and Migration in Asia and the Pacific. Manila.

Adger, W. Neil, Saleemul Huq, Katrina Brown, Declan Conway, and Mike Hulme. 2003. "Adaptation to Climate Change in the Developing World." Progress in Development Studies 3 (3): 179-95.

Adger, W. Neil, P. Mick Kelly, Alexandra Winkels, Luong Quang Huy, and Catherine Locke. 2002. "Migration, Remittances, Livelihood Trajectories, and Social Resilience." AMBIO: A Journal of the Human Environment 31 (4): 358-66.

Afifi, Tamer, Andrea Milan, Benjamin Etzold, Benjamin Schraven, Christina Rademacher-Schulz, Patrick Sakdapolrak, Alexander Reif, Kees van der Geest, and Koko Warner. 2015. "Human Mobility in Response to Rainfall Variability: Opportunities for Migration as a Successful Adaptation Strategy in Eight Case Studies." Migration and Development 5 (2): 254-74.

Aldrich, Daniel. 2011. "The Power of People: Social Capital's Role in Recovery from the 1995 Kobe Earthquake.” Natural Hazards 56 (3): 595-611.

Bardsley, Douglas K., and Graeme Hugo. 2010. "Migration and Climate Change: Examining Thresholds of Change to Guide Effective Adaptation Decision-Making." Population and Environment 32 (2/3): 238-62.

Barnett, Jon, and Michael Webber. 2010. "Accommodating Migration to Promote Adaptation to Climate Change.” World Bank Policy Research Working Paper No. 5270.

Bell, Martin, and Elin Charles-Edwards. 2013. Cross-National Comparisons of Internal Migration: An Update on Global Patterns and Trends. UNDESA: New York.

Black, Richard, Stephen R.G. Bennett, Sandy M. Thomas, and John R. Beddington. 2011. "Climate Change: Migration as Adaptation." Nature 478 (7370): 447-49.

Blaikie, Piers, Terry Cannon, lan Davis, and Ben Wisner. 1994. At Risk: Natural Hazards, People's Vulnerability, and Disasters. Routledge: New York.

Brock, Vicki Tinnon, and Bimal Kanti Paul. 2003. "Public Response to a Tornado Disaster: The Case of Hoisington, Kansas.” Papers of the Applied Geography Conferences 26: 343-351.

Brown, Richard, John Connell, and Eliana Jimenez-Soto. 2014. "Migrants' Remittances, Poverty and Social Protection in the South Pacific: Fiji and Tonga." Population, Space and Place 20 (5): 434-54.

Bryan, Gharad, Shyamal Chowdhury, and Mushfiq Mobarak. 2014. "Under-Investment in a Profitable Technology: The Case of Seasonal Migration in Bangladesh.” Econometrica 82 (5): 1671-748.

Call, Maia, Clark Gray, Michael Emch, and Mohammad Yunus. 2017. “Disruption, not Displacement: Environmental Variability and Temporary Migration in Bangladesh." Global Environmental Change 46: 157-65. 
Cannon, Terry. 1994. "Vulnerability Analysis and the Explanation of "Natural" Disasters." In Disasters, Development and Environment, edited by Ann Varley. Chichester: John Wiley \& Sons.

Chan, Faith Ka Shun, Gordon Mitchell, Olalekan Adekola, and Adrian McDonald. 2012. "Flood Risk in Asia's Urban Mega-Deltas: Drivers, Impacts and Response." Environment and Urbanization ASIA 3 (1): 41-61.

Chan, Kam Wing. 2013. "China: Internal Migration.” In The Encyclopedia of Global Human Migration, edited by Immanuel Ness. Hoboken: Blackwell Publishing Ltd.

Chun, Jane. 2014. "Livelihoods Under Stress: Critical Assets and Mobility Outcomes in the Mekong Delta, Viet Nam.” Migration, Environment and Climate Change Policy Brief Series. Geneva: International Organization for Migration.

Curtis, Katherine, Elizabeth Fussell, and Jack DeWaard. 2015. "Recovery Migration after Hurricanes Katrina and Rita: Spatial Concentration and Intensification in the Migration System.” Demography 52 (4): 1269-93.

Davis, Jason, and David Lopez-Carr. 2010. "The Effects of Migrant Remittances on PopulationEnvironment Dynamics in Migrant Origin Areas: International Migration, Fertility, and Consumption in Highland Guatemala." Population and Environment 32 (2-3): 216-37.

Deshingkar, Priya. 2012. "Environmental Risk, Resilience and Migration: Implications for Natural Resource Management and Agriculture." Environmental Research Letters 7 (1):1-7.

Deshingkar, Priya, and Mohamed Aheeyar. 2006. "Remittances in Crises: Sri Lanka after the Tsunami." An HPG Background Paper. London: Overseas Development Institute.

DeWaard, Jack, Katherine Curtis, and Elizabeth Fussell. 2016. "Population Recovery in New Orleans after Hurricane Katrina: Exploring the Potential Role of Stage Migration in Migration Systems." Population and Environment 37 (4): 449-63.

Drabek, Thomas E., and Keith S. Boggs. 1968. “Families in Disaster: Reactions and Relatives.” Journal of Marriage and the Family (30): 443-51.

Ebeke, Christian, and Jean-Louis Combes. 2013. "Do Remittances Dampen the Effect of Natural Disasters on Output Growth Volatility in Developing Countries?" Applied Economics 45 (16): 2241-54.

Findlay, Allan, and Alistair Geddes. 2011. "Critical Views on the Relationship between Climate Change and Migration: Some Insights from the Experience of Bangladesh." In Migration and Climate Change, edited by Etienne Piguet, Antoine Pecoud, and Paul de Guchteneire. UNESCO/Cambridge University Press.

Food and Agriculture Organization (FAO) and World Food Programme (WFP). 2012. FAO/WFP Crop and Food Security Update Mission to Cambodia: Report. Rome: FAO/WFP. 
Fussell, Elizabeth, Narayan Sastry, and Mark VanLandingham. 2010. "Race, Socioeconomic Status, and Return Migration to New Orleans after Hurricane Katrina." Population and Environment 31 (1-3): $20-42$.

Geddes, Andrew, and Andrew Jordan. 2012. "Migration as Adaptation? Exploring the Scope for Coordinating Environmental and Migration Policies in the European Union." Environment and Planning C: Politics and Space 30 (6): 1029-44.

Ginnetti, Justin, and Chris Lavell. 2015. "The Risk of Disaster Induced Displacement in South Asia." Technical Paper. Geneva: IDMC.

Gioli, Giovanna, Talimand Khan, Suman Bisht, and Jürgen Scheffran. 2014. "Migration as an Adaptation Strategy and Its Gendered Implications: A Case Study from the Upper Indus Basin." Mountain Research and Development 34 (3): 255-66.

Gray, Clark, Elizabeth Frankenberg, Thomas Gillespie, Cecep Sumantri, and Duncan Thomas. 2014. "Studying Displacement after a Disaster Using Large Scale Survey Methods: Sumatra after the 2004 Tsunami." Annals of the Association of American Geographers 104 (3): 594-612.

Gray, Clark, and Valerie Mueller. 2012a. "Drought and Population Mobility in Rural Ethiopia.” World Development 40 (1): 134-45.

_. 2012b. "Natural Disasters and Population Mobility in Bangladesh." Proceedings of the National Academy of Sciences 109 (16): 6000-6005.

Greiner, Clemens. 2011. "Migration, Translocal Networks and Socio-Economic Stratification in Namibia." Africa 81 (4): 606-27.

Greiner, Clemens, and Patrick Sakdapolrak. 2013. "Translocality: Concepts, Applications and Emerging Research Perspectives.” Geography Compass 7 (5): 373-84.

Gubert, Flore. 2002. "Do Migrants Insure Those Who Stay behind? Evidence from the Kayes Area (Western Mali)." Oxford Development Studies 30 (3): 267-87.

Halliday, Timothy. 2006. "Migration, Risk and Liquidity Constraints in El Salvador." Economic Development and Cultural Change 54 (4): 893-925.

Harper, Robin A., and Hani Zubida. 2017. "Being Seen: Visibility, Families and Dynamic Remittance Practices.” Migration and Development 7 (1): 5-25.

Hugo, Graeme. 1996. “Environmental Concerns and International Migration.” International Migration Review 30 (1): 105-31.

_ 2006. "Migration, Development and Environment." IOM Migration Research Series. Geneva: International Organization for Migration.

Hunter, Lori. 2005. "Migration and Environmental Hazards." Population and Environment 26 (4): 273-302. 
14 | References

2018. Global Report on Internal Displacement 2018. Geneva: Internal Displacement Monitoring Centre.

Ikeda, Keiko. 1995. "Gender Differences in Human Loss and Vulnerability in Natural Disasters: A Case Study from Bangladesh." Indian Journal of Gender Studies 2 (2): 171-93.

Intergovernmental Panel on Climate Change (IPCC). 2013. Climate Change 2013: The Physical Science Basis. Contribution of Working Group I to the Fifth Assessment Report of the Intergovernmental Panel on Climate Change. Cambridge, UK and New York, US: Cambridge University Press. https://www.ipcc.ch/site/assets/uploads/2018/02/WG1AR5_all_final.pdf.

Internal Displacement Monitoring Centre (IDMC). 2015. Global Estimates 2015: People Displaced by Disasters. Geneva.

International Organization for Migration (IOM). 2018. World Migration Report. Geneva.

Jennings, Julia, and Clark Gray. 2017. “Climate and Marriage in the Netherlands, 1871-1937." Population and Environment 38 (3): 242-60.

Kagan, Sophia. 2016. "The Role of Remittances in Risk Management and Resilience in Tuvalu: Evidence and Potential Policy Responses." In Migration, Risk Management and Climate Change: Evidence and Policy Responses, edited by Andrea Milan, Benjamin Schraven, Koko Warner, and Noemi Cascone. Switzerland: Spring International Publishing.

Kartiki, Kartha. 2011. "Climate Change and Migration: A Case Study from Rural Bangladesh." Gender and Development 19 (1): 23-38.

Koubi, Vally, Tobias Böhmelt, Gabriele Spilker, and Lena Schaffer. 2016. "The Role of Environmental Perceptions in Migration Decision-Making: Evidence from Both Migrants and Non-Migrants in Five Developing Countries." Population and Environment 38 (2): 134-63.

Kurien, Prema. A. 2008. A Socio-Cultural Perspective on Migration and Economic Development: Middle Eastern Migration from Kerala, India. Geneva: International Organization for Migration.

Lavell, Allan. 1994. "Opening a Policy Window: The Costa Rican Hospital Retrofit and Seismic Insurance Programs 1986-1992." International Journal of Mass Emergencies and Disasters 12 (1): 95-115.

Le Dé, Loïc, JC Gaillard, and Wardlow Friesen. 2015. "Poverty and Disasters: Do Remittances Reproduce Vulnerability?” Journal of Development Studies 51 (5): 538-53.

Le Dé, Loïc, JC Gaillard, Wardlow Friesen, Meressapinni Pupualii, C. Brown, A. Aupito. 2015. "Our Family Comes First: Migrants' Perspectives on Remittances in Disaster." Migration and Development 5 (1): 1-19.

Lee, Everett. 1966. “A Theory of Migration.” Demography 3 (1): 47-57. 
Lein, Haakon. 2000. "Hazards and 'Forced' Migration in Bangladesh." Norsk Geografisk TidsskriftNorwegian Journal of Geography 54 (3): 122-27.

Levitt, Peggy. 1998. "Social Remittances: Migration Driven Local-Level Forms of Cultural Diffusion.” The International Migration Review 32 (4): 926-48.

Lewis, James. 1999. Development in Disaster-Prone Places: Studies of Vulnerability. London: Intermediate Technology Publications Ltd.

Licuanan, Victoria, Omar Mahmoud Toman, and Andreas Steinmayr. 2012. "The Drivers of Diaspora Donations for Development: Evidence from the Philippines.” Kiel Working Paper No. 1807.

Lu, Xin, David J. Wrathall, Pål Roe Sundsøy, Md. Nadiruzzaman, Erik Wetter, Asif lqbal, Taimur Qureshi, Andrew Tatem, Geoffrey Canright, Kenth Engø-Monsen, and Linus Bengtsson. 2016a. "Unveiling Hidden Migration and Mobility Patterns in Climate Stressed Regions: A Longitudinal Study of Six Million Anonymous Mobile Phone Users in Bangladesh." Global Environmental Change 38: 1-7.

_. 2016b. "Detecting Climate Adaptation with Mobile Network Data in Bangladesh: Anomalies in Communication, Mobility and Consumption Patterns during Cyclone Mahasen." Climatic Change 138 (3-4): 505-19.

Mallick, Bishawjit. 2014. "Cyclone-Induced Migration in Southwest Coastal Bangladesh.” ASIEN 130: $60-81$.

Mallick, Bishawjit, Bayes Ahmed, and Joachim Vogt. 2017. "Living with the Risks of Cyclone Disasters in the South-Western Coastal Region of Bangladesh.” Environments 4 (1): 13.

Mallick, Bishawjit, and Joachim Vogt. 2012. "Cyclone, Coastal Society and Migration: Empirical Evidence from Bangladesh.” International Development Planning Review 34 (3): 217-40.

- 2014. "Population Displacement after Cyclone and Its Consequences: Empirical Evidence from Coastal Bangladesh.” Natural Hazards 73 (2): 191-212.

Massey, Douglas, Joaquín Arango, Graeme Hugo, Ali Kouaouci, Adela Pellegrino, and J. Edward Taylor. 1993. "Theories of International Migration: A Review and Appraisal." Population and Development Review 19 (3): 431-66.

Massey, Douglas, William Axinn, and Dirgha Ghimire. 2007. "Environmental Change and OutMigration: Evidence from Nepal." Research Report. Ann Arbor: Population Studies Center.

Mazzucato, Valentina. 2011. "Reverse Remittances in the Migration-Development Nexus: Two-Way Flows between Ghana and the Netherlands." Population, Space and Place 17 (5): 454-68.

McLeman, Robert. 2014. Climate and Human Migration: Past Experiences, Future Challenges. New York: Cambridge University Press. 
McLeman, Robert, and Barry Smit. 2006. "Migration as an Adaptation to Climate Change." Climatic Change 76 (1-2): 31-53.

Mendelsohn, Robert, Pradeep Kurukulasuriya, Alan Basist, Felix Kogan, Claude Williams. 2007. "Climate Analysis with Satellite Versus Weather Station Data." Climatic Change 81 (1): 71-83.

Mohapatra, Sanket, George Joseph, and Dilip Ratha. 2012. "Remittances and Natural Disasters: Ex-Post Response and Contribution to Ex-Ante Preparedness." Environment, Development and Sustainability 14 (3): 365-87.

Mueller, Valerie, Clark Gray, and Khalid Kosec. 2014. "Heat Stress Increases Long-Term Human Migration in Rural Pakistan." Nature Climate Change 4 (3): 182-85.

Naik, Asmita. 2009. "Migration and Natural Disasters." In Migration, Environment and Climate Change: Assessing the Evidence, edited by Frank Laczko and Christine Aghazarm. Geneva: International Organization for Migration.

Nansen Initiative. 2014. "Human Mobility in the Context of Disasters and Climate Change in Southeast Asia." Background Paper. Geneva: Nansen Initiative.

Nepal Risk and Reduction Consortium (NRRC). 2014. Understanding the Role of Remittances in Reducing Earthquake Risk. Humanitarian Innovation Fund.

Ober, Kayly. 2014. Migration as Adaptation: Exploring Mobility as a Coping Strategy for Climate Change. Oxford: UK Climate Change and Migration Coalition.

O'Brien, Karen L., and Robin M. Leichenko. 2000. "Double Exposure: Assessing the Impacts of Climate Change within the Context of Economic Globalization." Global Environmental Change 10 (3): 221-32.

Parker, Dennis, Nabiul Islam, and Ngai Weng Chen. 1997. "Reducing Vulnerability Following Flood Disasters: Issues and Practices." In Reconstruction After Disaster: Issues and Practices, edited by Adenrele Awotona. Aldershot: Ashgate.

Paul, Bimal Kanti. 2005. "Evidence against Disaster-Induced Migration: The 2004 Tornado in NorthCentral Bangladesh.” Disasters 29 (4): 370-85.

Paul, Shitangsu K., and Jayant K. Routray. 2010. "Flood Proneness and Coping Strategies: The Experiences of Two Villages in Bangladesh.” Disasters 34 (2): 489-508.

Penning-Rowsell, Edmund C., Parvin Sultana, and Paul M. Thompson. 2013. "The 'Last Resort'? Population Movement in Response to Climate-Related Hazards in Bangladesh." Environmental Science \& Policy 27 (Supplement 1): 44-59.

Peth, Simon A., and Patrick Sakdapolrak. "When the Origin Becomes the Destination: Lost Remittances and Social Resilience of Transnational Return Migrants in Thailand." Area (Under Review).

Plane, David. 1993. “Demographic Influences on Migration.” Regional Studies 27 (4): 375-83. 
Quartey, Peter, and Theresa Blankson. 2004. "Do Migrant Remittances Minimize the Impact of Macrovolatility on the Poor in Ghana?” Report to Global Development Network. Washington, DC.

Rahman Munshi K., Bimal K. Paul, Andrew Curtis, and Thomas W. Schmidlin. 2015. "Linking Coastal Disasters and Migration: A Case Study of Kutubdia Island, Bangladesh." Professional Geographer 67 (2): 218-28.

Raleigh, Clionadh, Lisa Jordan, and Idean Salehyan. 2008. Assessing the Impact of Climate Change on Migration and Conflict. Washington, DC: World Bank.

Renaud, Fabrice, Olivia Dun, Koko Warner, and Janos Bogardi. 2011. "A Decision Framework for Environmentally Induced Migration.” International Migration 49 Suppl. s1: 5-29.

Rigaud, Kanta Kumari, Alex de Sherbinin, Bryan Jones, Jonas Bergmann, Viviane Clement, Kayly Ober, Jacob Schewe, Susana Adamo, Brent McCusker, Silke Heuser, and Amelia Midgley. 2018. Groundswell: Preparing for Internal Climate Migration. Washington, DC: World Bank.

Rigg, Jonathan, Tuan Anh Nguyen, and Thi Thu Huong Luong. 2014. "The Texture of Livelihoods: Migration and Making a Living in Hanoi." The Journal of Development Studies 50 (3): 368-82.

Rigg, Jonathan, Buapun Promphaking, and Ann Le Mare. 2014. "Personalizing the Middle-Income Trap: An Inter-Generational Migrant View from Rural Thailand." World Development 59 (7): 184-98.

Rigg, Jonathan, and Albert Salamanca. 2009. "Managing Risk and Vulnerability in Asia: A 25-Year Village Study from Thailand." Asia Pacific Viewpoint 50 (3): 255-70.

2011. "Connecting Lives and Places: Mobility and Spatial Signatures in Northeast Thailand, 1982-2009." Critical Asian Studies 43 (4): 551-75.

2015. "The Devil in the Detail: Interpreting Livelihood Turbulence from a 25-Year Panel Study from Thailand.” Area 47 (3): 296-304.

Rigg, Jonathan, Albert Salamanca, and Michael J.G. Parnwell. 2012. "Joining the Dots of Agrarian Change in Asia: 25 Year View from Thailand.” World Development 40 (7): 1469-81.

Rockenbauch, Till, and Patrick Sakdapolrak. 2017. "Social Networks and the Resilience of Rural Communities in the Global South: A Critical Review and Conceptual Reflections." Ecology and Society 22 (1). https://www.ecologyandsociety.org/vol22/iss1/art10/.

- 2019. "Do Translocal Networks Matter for Agricultural Innovation? A Case Study on Advice Sharing in Small-Scale Farming Communities in Northeast Thailand." Agriculture and Human Values. https://link.springer.com/article/10.1007/s10460-019-09935-0.

Sakdapolrak, Patrick, Sopon Naruchaikusol, Kayly Ober, Simon Peth, Luise Porst, Till Rockenbauch, and Vera Tolo. 2016. "Migration in a Changing Climate: Towards a Translocal Social Resilience Approach.” Die Erde 147 (2): 81-94. 
18 | References

Scheffran, Jürgen, Elina Marmer, and Papa Sow. 2012. "Migration as a Contribution to Resilience and Innovation in Climate Adaptation: Social Networks and Co-development in Northwest Africa." Applied Geography 33 (1): 119-27.

Schneider, Stephen H. 2004. “Abrupt Non-Linear Climate Change, Irreversibility and Surprise.” Global Environmental Change 14 (3): 245-58.

Scoones, lan. 1998. "Sustainable Rural Livelihoods: A Framework for Analysis." IDS Working Paper No. 72. Brighton, UK: Institute for Development Studies.

Smith, Keith, and Roy Ward. 1998. Floods: Physical Processes and Human Impacts. New York: John Wiley \& Sons.

Smith, Stanley, and Christopher McCarty. 1996. "Demographic Effects of Natural Disasters: A Case Study of Hurricane Andrew.” Demography 33 (2): 265-75.

Stark, Oded, and David E. Bloom. 1985. "The New Economics of Labor Migration." American Economic Review 75 (2): 173-78.

Streets, David G., and Michael H. Glantz. 2000. "Exploring the Concept of Climate Surprise." Global Environmental Change 10 (2): 97-107.

Suleri, Abid Qaiyum, and Kevin Savage. 2006. "Remittances in Crises: A Case Study from Pakistan.” An HPG Background Paper. London: Overseas Development Institute.

Szabo, Sylvia, W. Neil Adger, and Zoe Matthews. 2018. "Home Is Where the Money Goes: MigrationRelated Urban-Rural Integration in Delta Regions." Migration and Development 7 (2): 163-79.

Tacoli, Cecilia. 2011. Not Only Climate Change: Mobility, Vulnerability and Socio-Economic Transformations in Environmentally Fragile Areas in Bolivia, Senegal and Tanzania. London: International Institute for Environment and Development.

Tunas, Devisari, and Andrea Peresthu. 2010. "The Self-Help Housing in Indonesia: The Only Option for the Poor?” Habitat International 34 (3): 315-22.

United Nations Department of Economic and Social Affairs (UNDESA). 2015. International Migrant Stock 2015. New York.

United Nations Development Programme (UNDP). 2009. Human Development Report 2009. New York. http://hdr.undp.org/sites/default/files/reports/269/hdr_2009_en_complete.pdf.

United Nations Office for Disaster Risk Reduction (UNDRR). 2018. Terminology. Geneva. https://www.unisdr.org/we/inform/terminology.

Warner, Koko. 2012. "Human Migration and Displacement in the Context of Adaptation to Climate Change: The Cancun Adaptation Framework and Potential for Future Action." Environment and Planning C: Politics and Space 30 (6): 1061-77. 
Warner, Koko, and Tamer Afifi. 2014. "Where the Rain Falls: Evidence from 8 Countries on How Vulnerable Households Use Migration to Manage the Risk of Rainfall Variability and Food Insecurity." Climate and Development 6 (1): 1-17.

Wilson, Robin, Elisabeth Zu Erbach-Schoenberg, Maximilian Albert, Daniel Power, Simon Tudge, Miguel Gonzalez, Sam Guthrie, Heather Chamberlain, Christopher Brooks, Christopher Hughes, Lenka Pitonakova, Caroline Buckee, Xin Lu, Erik Wetter, Andrew Tatem, and Linus Bengtsson. 2016. "Rapid and Near Real-Time Assessments of Population Displacement Using Mobile Phone Data Following Disasters: The 2015 Nepal Earthquake.” PLOS Current Disasters.

World Bank. 2013. World Development Report 2014: Risk and Opportunity-Managing Risk for Development. Washington, DC.

2016. Forcibly Displaced: Toward a Development Approach Supporting Refugees, the Internally Displaced, and Their Hosts. Washington, DC.

WorldRiskReport. 2017. WorldRiskReport: Analysis and Prospects 2017. BerlinL Bündnis Entwicklung Hilft.

Wu, Treena. 2006. "The Role of Remittances in Crisis: An Aceh Research Study." An HPG Background Paper. London: Overseas Development Institute.

Yang, Dean, and HwaJung Choi. 2007. "Are Remittances Insurance? Evidence from Rainfall Shocks in the Philippines.” World Bank Economic Review 21 (2): 219-48.

Yonetani, Michelle. 2012. Global Estimates 2011, People Displaced by Natural Hazard-Induced Disasters. Geneva: Internal Displacement Monitoring Centre. 


\section{The Links between Climate Change, Disasters, Migration, and Social Resilience in Asia: A Literature Review}

Disasters are increasingly causing mass movements of people all over the world, but especially in Asia. While sheer numbers are important, they tell us little about how disasters impact the movement of people in Asia, and to what extent they affect people's ability to overcome poverty and build their resilience. This paper seeks to move from numbers to nuances. In what ways do disasters determine where, when, and how people move? How do disasters affect this movement across differentiated segments of society, including socioeconomic status, gender, and age? In what ways does migration affect vulnerability and resilience in the face of disaster?

\section{About the Asian Development Bank}

ADB is committed to achieving a prosperous, inclusive, resilient, and sustainable Asia and the Pacific, while sustaining its efforts to eradicate extreme poverty. Established in 1966, it is owned by 68 members - 49 from the region. Its main instruments for helping its developing member countries are policy dialogue, loans, equity investments, guarantees, grants, and technical assistance. 